\title{
Comparative cytogenetic studies in species of the subfamily Cal- lichthyinae (Teleostei: Siluriformes: Callichthyidae)
}

\author{
Shimabukuro-Dias Cristiane Kioko $^{1}$, Claudio Oliveira ${ }^{1, *}$ and Fausto Foresti ${ }^{1}$ \\ ${ }^{1}$ Departamento de Morfologia, Instituto de Biociências, Universidade Estadual Paulista, 18618-000, Botucatu, SP, \\ Brazil.
}

\begin{abstract}
In the present study, the karyotype of three species (nine populations) of the Callichthyinae subfamily were investigated with the objective of better understanding the pattern of relationship among the genera that compose the subfamily. Among the four populations of Callichthys callichtbys studied, two showed $2 \mathrm{n}=56$ chromosomes and two $2 \mathrm{n}=58$ chromosomes. Up to eight additional microchromosomes were observed in the sample from Marilia. The three populations of Hoplosternum littorale displayed the same number of chromosomes, $2 \mathrm{n}=60$, and karyotypic constitution, $6 \mathrm{M}+2 \mathrm{SM}+52 \mathrm{~A}$. The two populations of Megalechis personata showed $2 \mathrm{n}=62$ chromosomes and similar karyotypic formulae, $8 \mathrm{M}+54 \mathrm{~A}$ and $6 \mathrm{M}+2 \mathrm{SM}+54 \mathrm{~A}$. Terminal Ag-NORs were found in one chromosome pair of $C$. callichthys, H. littorale, and M. personata from Itiquira, and in two pairs in M. personata from Rio Branco. The populations of C. callichthys showed C-band positive segments in centromeric and pericentromeric position and the populations of $H$. littorale and $M$. personata exhibited C-band positive segments in centromeric and/or interstitial position. Contrarily to the extensive chromosome rearrangements verified in the Corydoradinae subfamily, in the Callichthyinae subfamily a small number of changes seems to have occurred in its karyotypic evolution.
\end{abstract}

Key words: Ag-NOR, C-band, chromosomes, fish cytogenetic, karyotypic evolution.

\section{INTRODUCTION}

The Callichthyidae family is composed by 177 species separated in two subfamilies, Corydoradinae and Callichthyinae (REIs 2003). The Corydoradinae subfamily is composed by the genus $A s p i-$ doras (18 species), Corydoras (143 species), and Brochis ( 3 species) and the Callichthyinae subfamily is formed by the genera Callichthys ( 2 species), Dianema (2 species), Hoplosternum (3 species), Lepthoplosternum (4 species), and Megalechis (2 species) (REIs 2003). According to the phylogeny proposed by ReIs (1998), based on morphological characters, Dianema and Hoplosternum compose one clade which is the sister group of Megalechis. Lepthoplosternum is the sister group of Megalechis, Dianema, and Hoplosternum and Callichthys is the most primitive genus in the subfamily.

Cytogenetic analysis conduced in the Callichthyinae subfamily showed that the diploid number in this group has a small variation, from

\footnotetext{
* Corresponding author: fax +55 14 3815-3744; e-mail: claudio@ibb.unesp.br.
}

$2 \mathrm{n}=52$ to $2 \mathrm{n}=66$ (Porto et al. 1992; Oliveira et al. 1993), when compared to the extensive karyotypic variability found among the Corydoradinae, mainly in the genus Corydoras, which diploid numbers range from $2 \mathrm{n}=40$ in Corydoras nattereri (Oliveira et al. 1990) to $2 \mathrm{n}=134$ in C. aeneus (TURNer et al. 1992). This difference in the karyotypic variability between both Callichthyidae subfamilies is positively related to the number of species that constitute each one; thus, while the genus Corydoras is the most speciose among the Siluriformes, the other genera of the Callichthyidae family have a small number of species.

In the present study the karyotype of three species of Callichthyinae are described, after the chromosome staining with Giemsa, the localization of nucleolus organizer regions with Silver Nitrate (Ag-NORs), and C-banding, with the objective of increasing the cytogenetic data in the group, searching for new elements that could be used in order to better understand the pattern of relationships among its genera.

\section{MATERIAL AND METHODS}

The cytogenetic studies were done with three species (nine populations) of the Callichthyinae 
subfamily. Their taxonomic position, collection site, and number and sex of the analyzed specimens are shown in Table 1. After processing, fishes were identified and stored as vouchers at the fish collection of Laboratório de Biologia de Peixes (LBP), Instituto de Biociências, Universidade Estadual Paulista, Botucatu, São Paulo, Brazil.

Chromosome preparations were carried out according to FORESTI et al. (1993). Silver-staining of the nucleolar organizer regions was performed according to the technique proposed by HowelL and BLACK (1981), the C-banding was performed as described by Sumner (1972). Chromosome morphology was determined on the basis of arm ratio as proposed by LEVAN et al. (1964) and chromosomes were classified as metacentrics $(\mathrm{M})$, submetacentrics (SM), subtelocentrics (ST) and acrocentrics $(\mathrm{A})$.

\section{RESULTS}

Among the four local populations of C. callichtbys studied, two from Marília and Corumbá had $2 n=56$ chromosomes (Fig. 1) and two from Pindamonhangaba and Embu-Guaçu had 2n=58 chromosomes (Fig. 2). In the population of Mar- ilia, the occurrence of 0 to 8 microchromosomes was observed (Fig. 1a). One specimen from the population of Corumbá exhibited a large additional $\mathrm{M}$ chromosome, with size similar to those of the first M pair (Fig. 1c). The three populations of $H$. littorale had the same number of chromosomes $(2 \mathrm{n}=60)$ and karyotypic constitution $(6 \mathrm{M}+2 \mathrm{SM}+52 \mathrm{~A})$ (Fig. 3a). The two samples of $M$. personata had $2 \mathrm{n}=62$ chromosomes and similar karyotypic formulae, $8 \mathrm{M}+54 \mathrm{~A}$ and $6 \mathrm{M}+2 \mathrm{SM}+54 \mathrm{~A}$, respectively (Figs. $3 \mathrm{a}$ and $3 \mathrm{~b}$ ). In the species in which males and females were analyzed, differences between the sexes were not observed.

Single terminal Ag-NORs, located in the short arm of the chromosomes were found in C. callichthys, $H$. littorale, and $M$. personata from Itiquira (Figs. 1 to 3). The species M. personata from Rio Branco had terminal Ag-NORs in two M pairs, located in the short arms of the first chromosome pair and in the long arm of the second chromosome pair (Fig. 3c). All populations of C. callichthys displayed size polymorphism in the $\mathrm{Ag}$ NORs (Figs. 1 and 2).

The populations of C. callichthys showed $\mathrm{C}$-band positive segments in centromeric position in almost all chromosomes (Fig. 4). The microchromosomes of $C$. callichthys from Marília were entirely C-band positives (Fig. 4a). In the speci-

Table 1 - Studied species, collection numbers (LBP), number and sex of the studied fish, collection sites, diploid number $(2 \mathrm{n})$ and karyotypic data obtained for the studied species.

\begin{tabular}{|c|c|c|c|c|c|c|c|}
\hline $\begin{array}{l}\text { Genera } \\
\text { and species }\end{array}$ & $\begin{array}{l}\text { Collec- } \\
\text { tion } \\
\text { number }\end{array}$ & $\begin{array}{l}\text { Number } \\
\text { of speci- } \\
\text { mens } \\
\delta^{\lambda} / \text { 우오 }\end{array}$ & Locality & $2 n$ & Karyotype & $\begin{array}{l}\text { Number } \\
\text { of Ag- } \\
\text { NORs- } \\
\text { bearing } \\
\text { pairs }\end{array}$ & $\begin{array}{l}\text { Number and } \\
\text { size of super- } \\
\text { numerary } \\
\text { chromosomes }\end{array}$ \\
\hline \multicolumn{8}{|l|}{ Callichthys } \\
\hline C. callichthys & 485 & $1 / 1$ & $\begin{array}{l}\text { Pombo stream, Marília, } \\
\text { São Paulo }\end{array}$ & 56 & $22 \mathrm{M}+16 \mathrm{SM}+18 \mathrm{ST}$ & 1 & $\begin{array}{l}0-8 \text { micro- } \\
\text { chromosomes }\end{array}$ \\
\hline C. callichthys & 622 & $4 / 1$ & $\begin{array}{l}\text { Convento stream, } \\
\text { Pindamonhangaba, } \\
\text { São Paulo }\end{array}$ & 58 & $18 \mathrm{M}+14 \mathrm{SM}+26 \mathrm{ST}$ & 1 & \\
\hline C. callichthys & 848 & $2 / 0$ & $\begin{array}{l}\text { Santa Rita stream, } \\
\text { Embu-Guaçu, São Paulo }\end{array}$ & 58 & $18 \mathrm{M}+16 \mathrm{SM}+24 \mathrm{ST}$ & 1 & \\
\hline C. callichthys & 1555 & $3 / 0$ & Corumbá, Mato Grosso & $56 / 57$ & $20 \mathrm{M}+16 \mathrm{SM}+20 \mathrm{ST}$ & 1 & $\begin{array}{l}1 \text { macro- } \\
\text { chromosome }\end{array}$ \\
\hline \multicolumn{8}{|l|}{ Hoplosternum } \\
\hline H. littorale & 569 & $2 / 1$ & $\begin{array}{l}\text { Guaíba river, Eldorado do } \\
\text { Sul, Rio Grande do Sul }\end{array}$ & 60 & $6 \mathrm{M}+2 \mathrm{SM}+52 \mathrm{~A}$ & 1 & \\
\hline H. littorale & 466 & $1 / 3$ & $\begin{array}{l}\text { Jurumirim reservoir, } \\
\text { Angatuba, São Paulo }\end{array}$ & 60 & $6 \mathrm{M}+2 \mathrm{SM}+52 \mathrm{~A}$ & 1 & \\
\hline H. littorale & 688 & $1 / 1$ & $\begin{array}{l}\text { Tributary of the Piraí river, } \\
\text { Poconé, Mato Grosso }\end{array}$ & 60 & $6 \mathrm{M}+2 \mathrm{SM}+52 \mathrm{~A}$ & 1 & \\
\hline \multicolumn{8}{|l|}{ Megalechis } \\
\hline M. personata & 1554 & $2 / 0$ & $\begin{array}{l}\text { Tributary of the Itiquira } \\
\text { river, Itiquira, Mato Grosso }\end{array}$ & 62 & $6 \mathrm{M}+2 \mathrm{SM}+54 \mathrm{~A}$ & 1 & \\
\hline M. personata & 921 & $1 / 1$ & $\begin{array}{l}\text { Almoço stream, Rio Branco, } \\
\text { Acre }\end{array}$ & 62 & $8 \mathrm{M}+54 \mathrm{~A}$ & 2 & \\
\hline
\end{tabular}




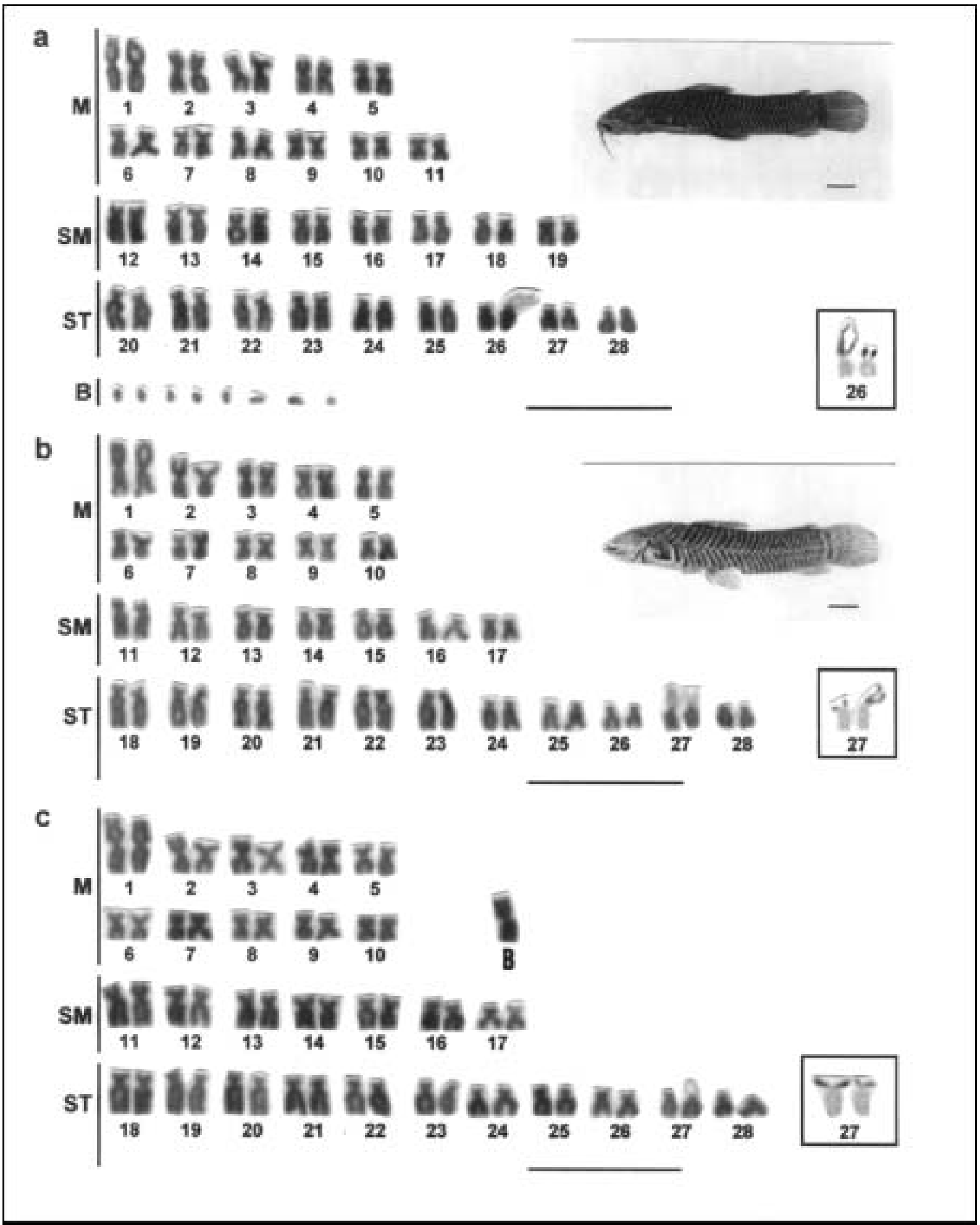

Fig. 1 - Karyotypes, Ag-NORs and specimens of: a) Callichthys callichthys from Marília, 2n=56, with eight additional supernumerary chromosomes (B); b) C. callichthys from Corumbá, 2n=56; and c) C. callichtbys from Corumbá, $2 \mathrm{n}=57$, with a putative additional supernumerary chromosome (B). Scale bars: $10 \mu \mathrm{m}$ (karyotype) and $10 \mathrm{~mm}$ (specimen). 


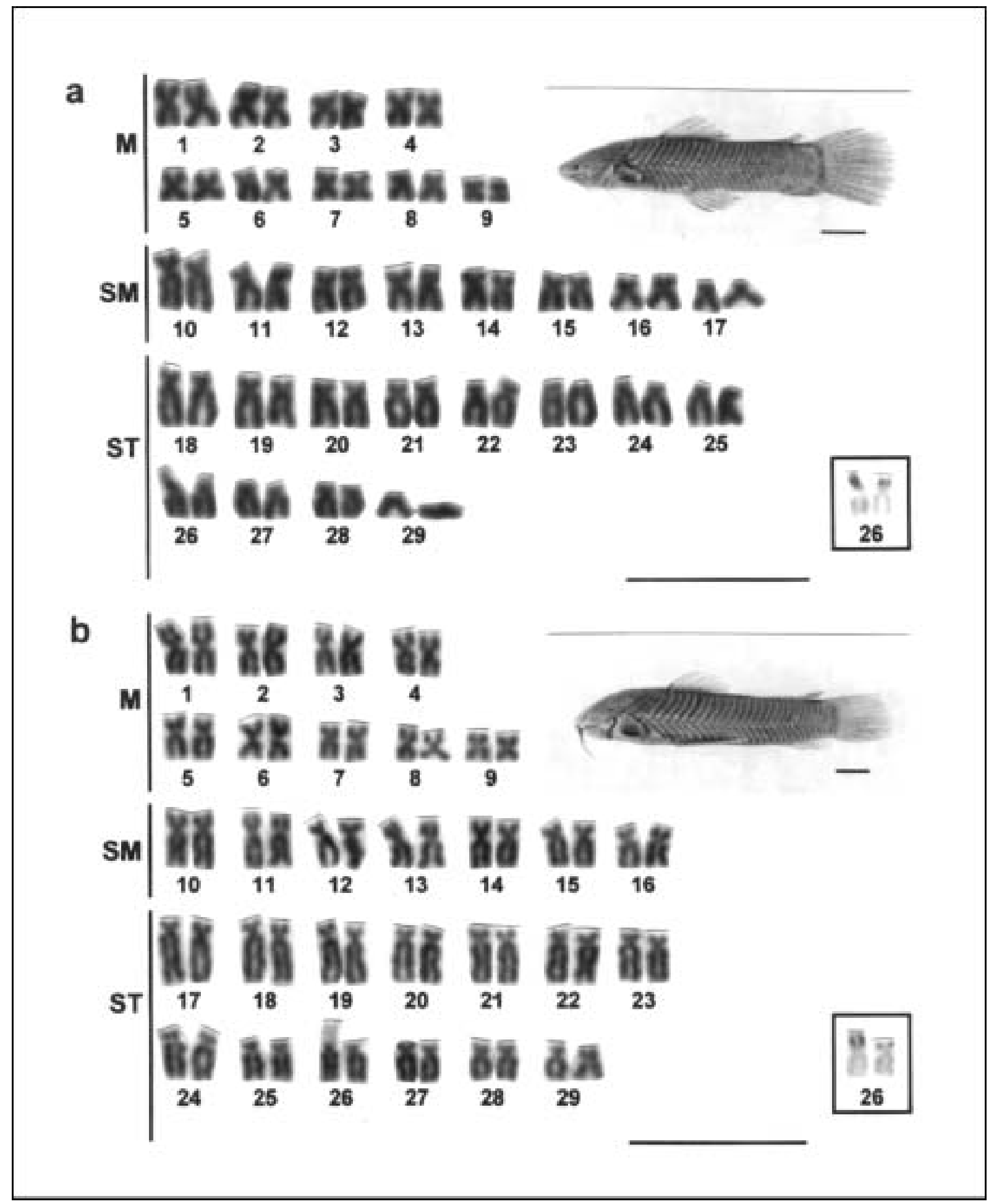

Fig. 2 - Karyotypes, Ag-NORs and specimens of: a) Callichthys callichthys from Embu-Guaçu, 2n=58; and b) C. callichthys from Pindamonhangaba, 2n=58. Scale bars: $10 \mu \mathrm{m}$ (karyotype) and $10 \mathrm{~mm}$ (specimen).

men of C. callichthys from Corumbá with $2 \mathrm{n}=57$ chromosomes, the additional $\mathrm{M}$ chromosome exhibited a small C-band positive segment in the centromeric position, and one of the homologues of the second M pair and of the first ST pair presented the short arms entirely C-band positive (Fig. 4c). The populations of $H$. littorale and the samples of $M$. personata had the C-band positive 

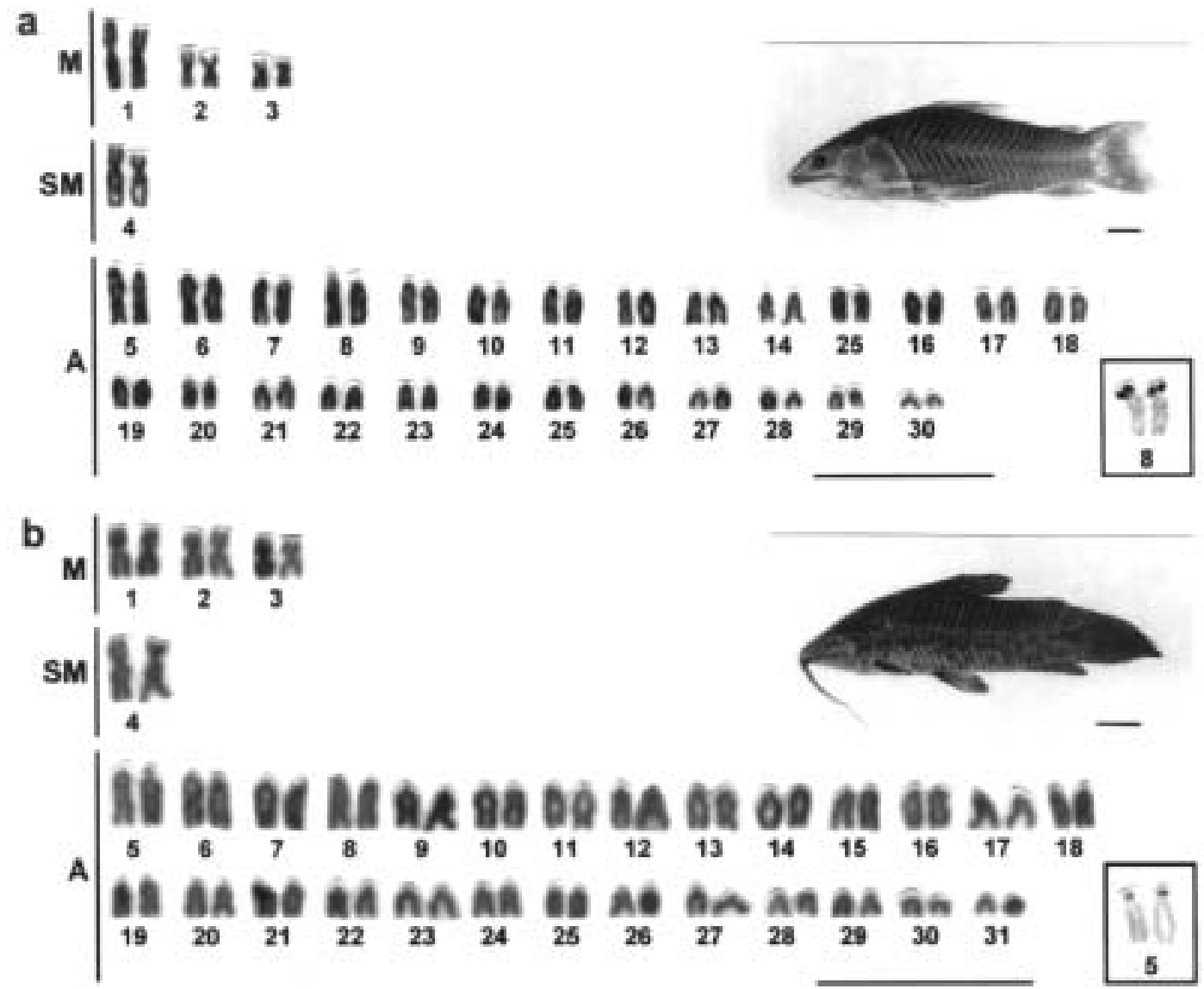

C

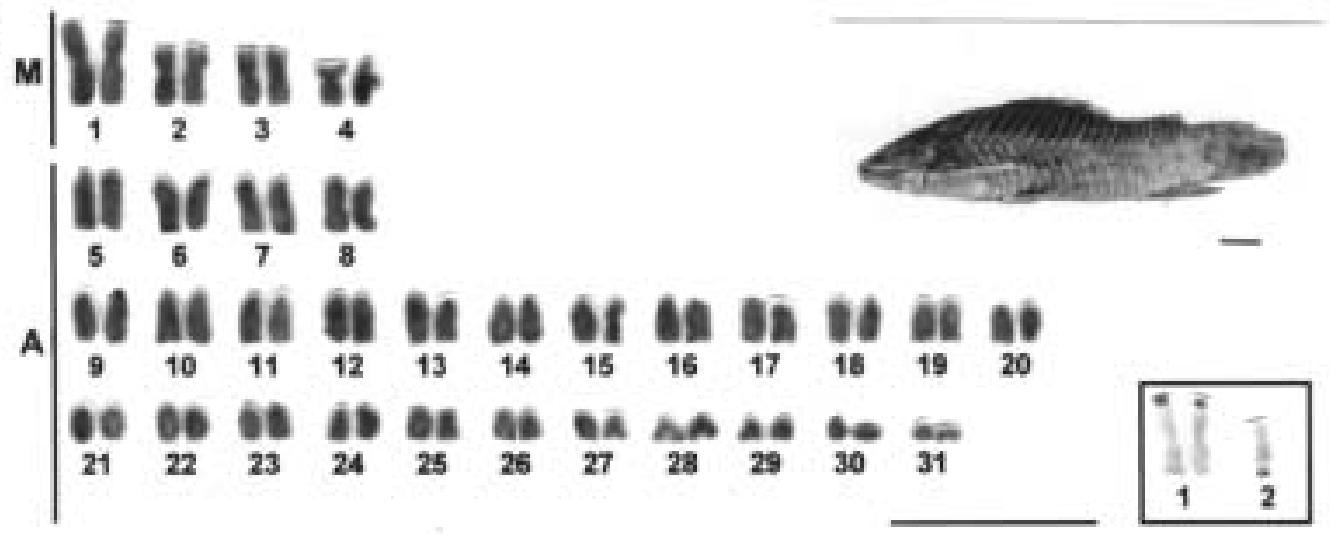

Fig. 3 - Karyotypes, Ag-NORs and specimens of: a) Hoplosternum littorale from Poconé, 2n=60; b) Megalechis personata from Itiquira, 2n=62; and c) Megalechis personata from Rio Branco, 2n=62. Scale bars: $10 \mu \mathrm{m}$ (karyotype) and $10 \mathrm{~mm}$ (specimen).

segments distributed in centromeric and/or interstitial position in all chromosomes (Fig. 5). The Ag-NORs were C-band positives in all analyzed species (Figs. 4 and 5).

\section{DISCUSSION}

The available data for $C$. callichthys showed that this species has a noticeable variation regard- ing to the diploid numbers, ranging from $2 \mathrm{n}=52$ to $2 \mathrm{n}=58$ chromosomes (PorTo et al. 1992; OLIVEIRA et al. 1993; present study), with the occurrence of several cytotypes in different Brazilian hydrographic basins. Thus, in the Parana-Paraguay basin three cytotypes, with different diploid numbers were found: one with $2 \mathrm{n}=54$, in the Paraná river in the municipality of Porto Rico (I. C. Martins Santos, personal communication); 


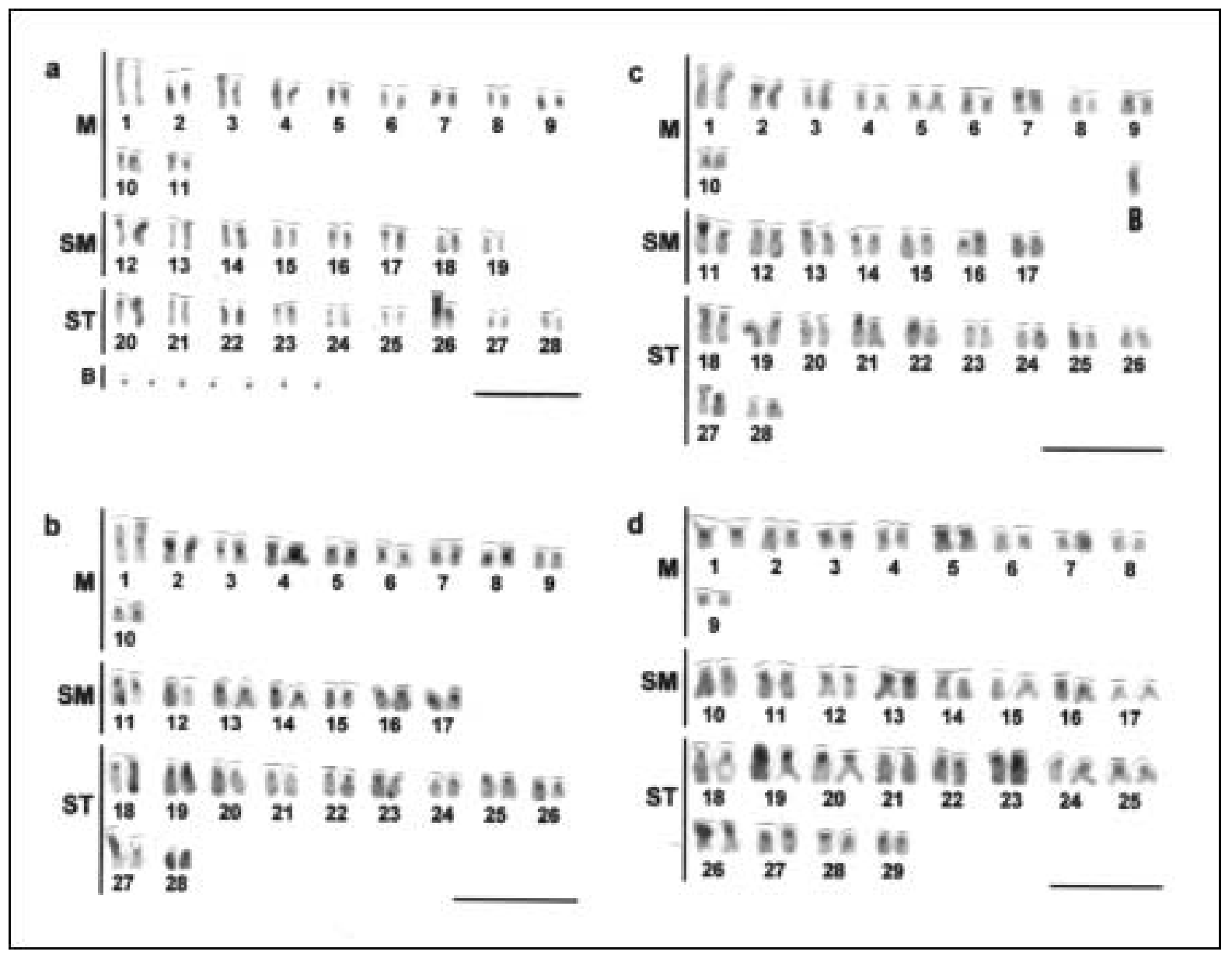

Fig. 4 - C-banded karyotypes. a) Callichthys callichtbys from Marília, 2n=56, with seven additional supernumerary chromosomes (B); b) C. callichthys from Corumbá, 2n=56; c) C. callichthys from Corumbá, $2 \mathrm{n}=57$, with a putative additional supernumerary chromosome (B); d) C. callichthys from Embu-Guaçu, 2n=58. Scale bars: $10 \mu \mathrm{m}$.

one with $2 \mathrm{n}=56$, in the north part of Argentina (Sanchez and Fenocchio 1996), in the Paraguay river in the municipality of Corumbá (present study), and in a tributary of Tietê river in the municipality of Marilia (present study); and one with $2 n=58$ in a tributary of right side of upper Tietê river in the municipality of Guarulhos (OliveIRA et al. 1993) and in a tributary of left side of upper Tietê river in the municipality Embu-Guaçu (present study).

While the cytotypes with $2 \mathrm{n}=56$ chromosomes have been found only in the Parana-Paraguay basin, cytotypes with $2 \mathrm{n}=58$ chromosomes have been found in freshwater coastal rivers in the South and Southeast Brazilian regions in the municipality of Tapes and Viamão (CALCAGNoto 1989), Itanhaém (Oliveira et al. 1993), and Pindamonhangaba (present study). Moreover, fish with $2 \mathrm{n}=58$ were also found in the Amazon basin (Porto et al. 1992). In the Amazon basin cyto- types with $2 \mathrm{n}=52$ and with $2 \mathrm{n}=54$ chromosomes were also found (PorTo et al. 1992).

From the taxonomic point of view, the genus Callichthys have only two valid species: C. callichthys and C. fabricioi; however, 13 species were already described and now these names are considered junior synonymous of $C$. callichthys (REIS 2003). The presence of different cytotypes in the species $C$. callichthys suggest the occurrence of several unidentified species, reinforcing the proposal of ReIs (1998), agreeing that the group needs a general taxonomic review.

Among the neotropical freshwater fish, supernumerary chromosomes, with different sizes, have been found in several families, such as Anostomidae, Characidae, Crenuchidae, Curimatidae, Parodontidae, Prochilodontidae, Callichthyidae, Loricariidae, Pimelodidae, Cichlidae, and Coregonidae (Salvador and Moreira-Filho 1992; Mizoguchi and Martins-Santos 1997; Vênere et al. 1999). In general the supernumerary chro- 
a
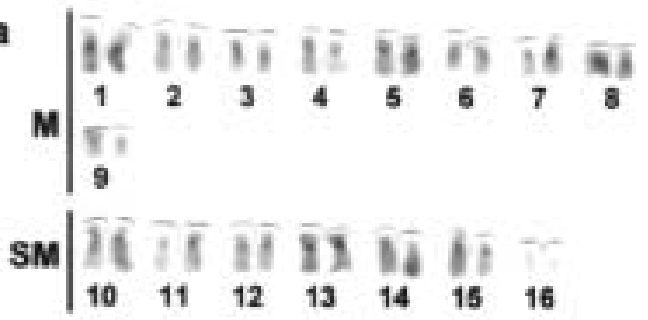

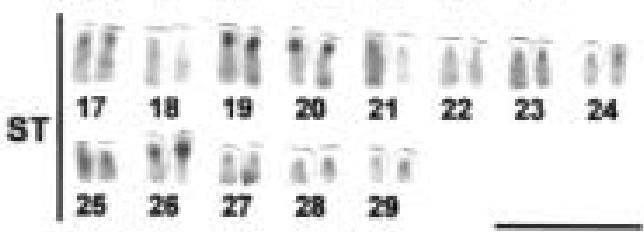

\section{b}

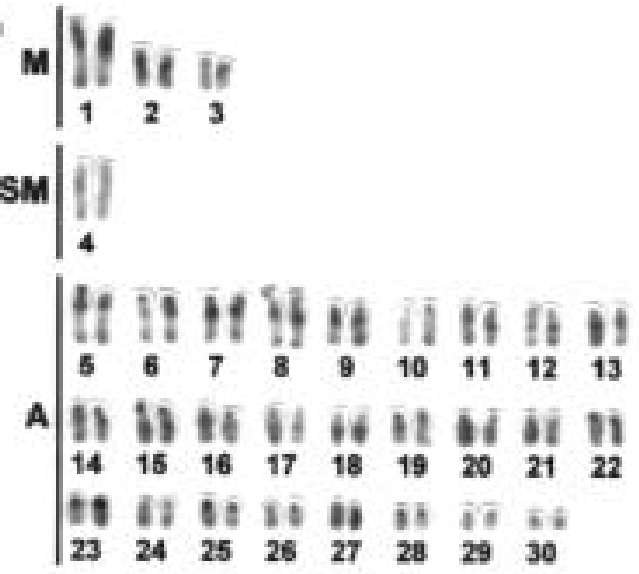

c
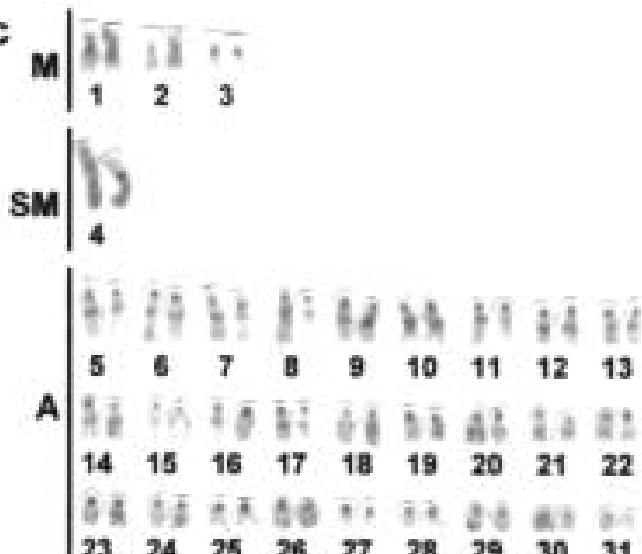

d

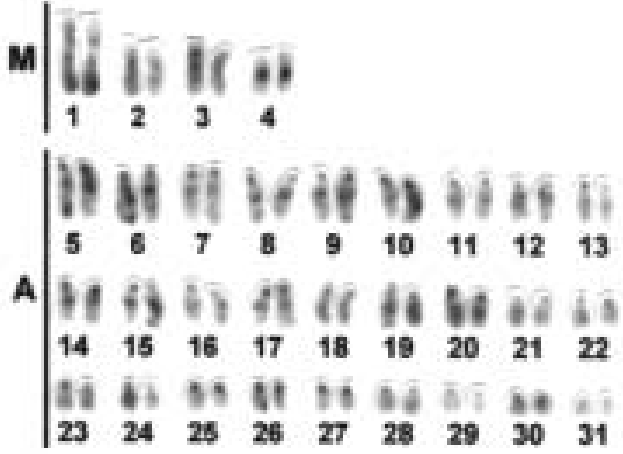

Fig. 5 - C-banded karyotypes. a) C. callichthys from Pindamonhangaba, 2n=58; b) Hoplosternum littorale from Poconé, 2n=60; c) Megalechis personata from Itiquira, 2n=62; and d) Megalechis personata from Rio Branco, $2 \mathrm{n}=62$. Scale bars: $10 \mu \mathrm{m}$.

mosomes are very small (microchromosomes) and their number range from one to two, with the exception of Moenkhausia sanctafilomenae (FORESTI et al. 1989) and C. callichtbys (CALCAGNoto 1989), which are species where up to eight and 16 microchromosomes, respectively were found. In a sample of $C$. callichthys from Itanhaém the presence of up to three supernumerary microchromosomes were found (OliveIra et al. 1993). In both samples of C. callichthys with supernumerary chromosomes previously studied, the specimens had $2 \mathrm{n}=58$. In the present study, an interesting characteristic observed in one specimen from Marília, with $2 \mathrm{n}=56$ chromosomes, was the presence of up to 8 microchromosomes, with the common characteristics found in the supernumerary chromo- somes. The existence of a cytotype with $2 \mathrm{n}=56$ and with supernumerary chromosomes is interesting because it shows that, besides de difference in the diploid number in the State of São Paulo, the supernumerary chromosomes in this genus are not restricted to the cytotypes with $2 \mathrm{n}=58$.

The occurrence of supernumerary chromosomes in C. callichthys was also described for a population from Argentina, municipality of Reconquista (SANCHEZ and Fenocchio 1996), in which was observed a diploid number of $2 \mathrm{n}=56$ and from one to two additional small size $\mathrm{M}$. In the Callichthyidae family, small supernumerary chromosomes were also described to Corydoras aeneus (Oliveira et al. 1988). The analysis of a sample of three specimens of $C$. callichthys from 
Corumbá (present study) showed that two had $2 \mathrm{n}=56$ chromosomes and a third one $2 \mathrm{n}=57$, being the additional chromosome a large $\mathrm{M}$. Although this additional chromosome could be a supernumerary chromosome, the analysis of the chromosomes of the fish with $2 \mathrm{n}=57$, after the $\mathrm{C}$ band staining, showed the presence of two chromosomes with only one homologue with the short arm C-band positive (pairs 2 and 11 in the Fig. 4c). The presence of this additional chromosome and at least two chromosome pairs without evident homologues permit to suggest that this fish with $2 \mathrm{n}=57$ could be a hybrid between fishes with $2 n=56$ and $2 n=58$ chromosomes, since these two cytotypes occur in the Paraná-Paraguay basin. The analysis of more specimens is required to resolve what this additional chromosome and the polymorphism of C-band actually mean.

All populations of $C$. callichthys analyzed in the present study had a single chromosome pair with $\mathrm{Ag}$-NORs and C-band positive segments mainly found in centromeric and pericentromeric positions, as described before (Oliveira et al. 1993; SANCHeZ and FenocChio 1996).

The three populations of Hoplosternum littorale studied had the same diploid number, karyotypic structure, number and position of Ag-NORs and pattern of distribution of C-band positive segments. These characteristics were also found in two other populations of $H$. littorale and for some specimens identified as Hoplosternum sp. (PоRTo and Feldberg 1992; Oliveira et al. 1993). Although, $H$. littorale is the species with wider geographic distribution among the Callichthyidae (REIS 1997), the karyotypic similarity among the populations studied suggest that this species may be introduced in some rivers where it was not found some years ago, such as in the rivers of the upper Parana basin.

The sample of Megalechis personata from Rio Branco had 2n=62 chromosomes and karyotypic structure very similar to those described for a population from the Araguaia river (VÊNERE 1998). The results obtained for the sample of $M$. personata from Itiquira were very similar to those obtained for the sample from Rio Branco although this sample was collected in the ParanaParaguay basin. Additionally, two samples described as Hoplosternum thoracatum and a sample described as $H$. aff. thoracatum, both names considered junior synonymous of Megalechis according to REIS (1997), had $2 \mathrm{n}=62,2 \mathrm{n}=64$, and 2n=66, respectively (PorTo and Feldberg 1992; Porto et al. 1992). While the populations of $M$. personata (VÊNERE 1998; present study) showed many A chromosomes, both samples studied by Porto and Feldberg (1992) and Porto et al. (1992) presented several M/SM chromosomes, suggesting the occurrence of several chromosomal rearrangements, as inversions, during the evolutionary history of the group. The presence of different cytotypes may also indicate the occurrence of undescribed species in the genus.

The presence of $2 \mathrm{n}=56$ chromosomes, single terminal NORs, and a small amount of centromeric heterochromatin are characteristics found in Diplomystes mesembrinus, a species that belongs to the most primitive family of the order Siluriformes, as well as in several other families of this order (Oliveira and Gosztonyi 2000). Additionally, several species of the Trichomycteridae family, a primitive sister group of Callichthyidae (De PINnA 1998) have 2n=54 chromosomes, single Ag-NORs and small C-band positive segments in centromeric position (LIMA and GALETTI JR. 1990; Torres et al. 1998; Borin and Santos 1999; Gonzo et al. 2000). Thus, the cytogenetic characteristics found in C. callichtbys, with diploid number ranging from $2 \mathrm{n}=52$ and $2 \mathrm{n}=58$, being three samples with $2 \mathrm{n}=56$ (SANCHEZ and FENосCHIO 1996; present study), several M/SM chromosomes, a single chromosome pair with AgNORs, and small C-band positive segments located in centromeric position, permit to suggest that Callichthys may be the most primitive genus of the Callichthyinae family. This hypothesis is in accordance with the phylogenetic position of this genus in a morphological phylogeny constructed by ReIs (1998).

The cytogenetic characteristics of Dianema, as $2 \mathrm{n}=60-62$ chromosomes, many ST/A chromosomes, a single chromosome pair with Ag-NORs, the pattern of distribution of C-band positive segments, and its low amount of nuclear DNA (OLIVEIRA et al. 1993) are similar to those observed in Hoplosternum littorale and Hoplosternum sp. (OliverRA et al. 1993), suggesting a close relationship between these genera, as proposed by OLIVEIRA et al. (1993). These data are in accordance with the phylogeny proposed by ReIs (1998), in which these two genera belong to a monophyletic group. Additionally, studies with the amount of nuclear DNA content showed that Dianema urostriata had the smallest value of the subfamily, 1.18 $\pm 0.07 \mathrm{pg}$ of DNA by diploid nuclei, followed by Hoplosternum sp., $1.36 \pm 0.11$, and two samples of C. callichthys, $1.89 \pm 0.24$ and $1.94 \pm 0.15$ (OLIVEIRA et al. 1993), reinforcing the hypothesis that Dianema and Hoplosternum are more related between themselves than to Callichthys (REIS 1998). 
The cytogenetic analyses conducted in the Callichthyinae subfamily showed the occurrence of two groups of species. The first group is composed by the genus Callichthys, that ranges from $2 \mathrm{n}=52$ to $2 \mathrm{n}=58$ chromosomes and many M/SM chromosomes. The second group include the other genera of the subfamily, being characterized by diploid number that ranges from $2 \mathrm{n}=60$ to $2 n=66$ chromosomes and high number of A chromosomes. Contrarily to the extensive chromosome rearrangements observed in the Corydoradinae subfamily, in the Callichthyinae subfamily a small number of chromosome changes seem to have occurred in the evolutionary history of the group. On the other hand, the karyotypic variability observed among the Callichthyinae suggest the existence of several undescribed species in this subfamily.

Acknowledgments - The authors are grateful to Renato Devidé for his technical assistance, to several friends for their valuable help in the collection of the specimens, and to Roberto E. Reis for the identification of the specimens. Funds supporting this study were provided by FAPESP and CNPq.

\section{REFERENCES}

Borin L.A. and Martins-SAntos I.C., 1999 - Karyotype characterization of three species of the genus Trichomycterus (Teleostei, Siluriformes) from the Iguaçu River basin. Genetica, 106: 215-221.

Calcagnoto D., 1989 - Variabilidade cromossômica na espécie Callichthys callichthys (Pisces, Siluriformes, Callichthyidae) de três localidades do Estado do Rio Grande do Sul. Bachelor Thesis. Universidade Federal do Rio Grande do Sul, Porto Alegre, Rio Grande do Sul, Brazil.

De Pinna M.C.C., 1998 - Phylogenetic relationships of Neotropical Siluriformes (Teleostei: Ostariophysi): bistorical overview and synthesis of bypotheses. In: L.R. Malabarba, R.E. Reis, R.P. Vari, Z.M.S. Lucena and C.A.S. Lucena (Eds.), "Phylogeny and Classification of Neotropical Fishes”, p. 279-330. EDIPUCRS, Porto Alegre.

Foresti F., Almeida-Toledo L.F. and Toledo S.A., 1989 - Supernumerary chromosome system, C-banding pattern characterization and multiple nucleolus organizer regions in Moenkhausia sanctaefilomenae (Pisces, Characidae). Genetica, 79: 107 114.

Foresti F., Oliveira C. and Almeida-Toledo L.F., 1993 - A method for chromosome preparations from large specimens of fishes using in vitro short treatment with colchicine. Experientia, 49: 810-813.

Gonzo G.M., Fenocchio A.S. and Pastori C., 2000 - Chromosome characterization of Trichomycterus spegazzini (Siluriformes, Trichomycteridae) from three bydrographic basins of the Northwest of Argentina. Caryologia, 53: 39-43.

Howell W.M. and Black D.A., 1981 - Controlled silver staining of nucleolus organizer regions with a protective colloidal developer: a 1-step method. Experientia, 36: 1014-1015.

Levan A., Fregda K. and Sandberg A.A., 1964 Nomenclature for centromeric position on chromosomes. Hereditas, 52: 201-220.

Lima N.R.W. and GaletTi JR. P.M., 1990 - Chromosome characterization of the fish Trichogenes longipinnis. A possible basic karyotype of Trichomycteridae. Rev. Bras. Genet. 13: 239-245.

Mizoguchi S.M.H.N. and Martins-Santos I.C., 1997 - Macro- and microchromosomes B in females of Astyanax scabripinnis (Pisces, Characidae). Hereditas, 127: 249-253.

Oliveira C. and Gosztonyi A.E., 2000 - A Cytogenetic study of Diplomystes mesembrinus (Teleostei, Siluriformes, Diplomystidae) with a discussion of chromosome evolution in siluriforms. Caryologia, 53:31-37.

Oliveira C., Almeida-Toledo L.F., Foresti F. and Toledo-Filho S.A., 1988 - Supernumerary chromosomes, robertsonian rearrangements and multiple NORs in Corydoras aeneus (Pisces, Siluriformes, Callichthyidae). Caryologia, 41: 227-236.

Oliveira C., Almeida-Toledo L.F., Foresti F., Britski H.A. and Toledo-Filho S.A., $1990-$ Comparative cytogenetic analysis of three cytotypes of Corydoras nattereri (Pisces, Siluriformes, Callichthyidae). Cytologia, 55: 21-26.

Oliveira C., Almeida-Toledo L.F., Mori L. and ToLEDo-FILHo S.A., 1993 - Cytogenetic and DNA content in six genera of the family Callichthyidae (Pisces, Siluriformes). Caryologia, 46: 171-188.

Porto J.I.R. and Feldberg E., 1992 - Comparative cytogenetic study of the armored catfishes of the genus Hoplosternum (Siluriformes, Callichthyidae). Rev. Brazil. Genet., 15: 359-367.

Porto J.I.R., Feldberg E., Nakayama C. and Falcao J.N., 1992 - A checklist of chromosome number and karyotypes of Amazonian freshwater fishes. Rev. Hydrobiol. Trop., 25: 287-299.

REIS R.E., 1997 - Revision of the neotropical catfish genus Hoplosternum (Ostariophysi: Siluriformes: Callichthyidae), with the description of two genera and three new species. Ichthyol. Explor. Freshwaters, 7: 299-326.

ReIs R.E., 1998 - Anatomy and phylogenetic analysis of the neotropical callichthyid catfishes (Ostariophysi, Siluriformes). Zool. J. Linn. Soc., 124: 105168.

REIS R.E., 2003 - Family Callichthyidae (armored catfishes). In: R.E. Reis, S.O. Kullander, C.J.F. Jr. (Eds.), "Check list of the freshwater fishes of South America”, p. 291-309. EDIPUCRS, Porto Alegre.

Salvador L.B. and Moreira-Filho O., 1992 - B chromosomes in Astyanax scabripinnis (Pisces, Characidae). Heredity, 69: 50-56. 
Sanchez S. and Fenocchio A.S., 1996 - Karyotypic studies and cytotaxonomic considerations on Callichthys callichthys (Pisces, Siluriformes) from Argentina. Cytologia, 61: 247-252.

Sumner A.T., 1972 - A simple technique for demonstrating centromeric beterochromatin. Exp. Cell Res., 75: 304-306.

Torres R.A., Foresti F. and Oliveira C., 1998 Comparative cytogenetic studies in alopatric populations of Trichomycterus paolence Eigenmann, 1918 from Southeastern Brazil (Siluriformes, Trichomycteridae). Cytologia 63: 107-114.

Turner B.J., Diffoot N. and Rasch E.M., 1992 The callichthyid catfish Corydoras aeneus is an unre- solved diploid-tetraploid sibling complex. Ichthyol. Explor. Freshwaters, 3: 17-23.

VêNERE P.C., 1998 - Diversificação cariotípica em peixes do médio rio Araguaia, com ênfase em Characiformes e Siluriformes (Teleostei, Ostariophysi). Doctoral Thesis. Universidade Federal de São Carlos, São Carlos, São Paulo, Brazil.

Vênere P.C., Miyazawa C.S. and Galetti Jr. P.M., 1999 - New cases of supernumerary chromosome in characiform fishes. Genet. Mol. Biol., 22: 345-349.

Received 17.2.2004; accepted 12.6.2004 